to tackling the "Raj Quartet" (The fewel in the Crown, The Day of the Scorpion, The Towers of Silence, and A Division of the Spoils) by Paul Scott, who in some 2000 pages of strong narrative describes the last years of the British raj in India. He focuses on a limited number of events, exploring them through the eyes of a limited number of characters, each of whom provides a particular version of the story or part of it. British and Indian, Anglo-Indian, Hindu and Muslim, the military and civilian authorities contribute their conflicting views of events, creating a convincing world in which social, political, and personal themes are skilfully interwoven, a world in which there are but few points where different minds succeed in meeting. Much of the work has a testamentary quality, judgment being left to the reader, who is allowed or indeed forced to take a view. While wading through so many pages of concentrated writing, there is need for time off occasionally and some of this time was pleasantly spent with several of H R F Keating's "whodunits," in which Inspector Ghote of the Bombay CID unravels mystery and murder in the subcontinent, already brought to life by Paul Scott.

One of the pluses of being ill is receiving get well wishes by mouth or card, sometimes accompanied by fruit or reading matter. John le Carré's most recent novel The Little Drummer Girl, as usual a gripping, somewhat tortuous story of conflicting loyalties, this time set in the Middle East, was one such offering that I enjoyed very much. The heroine, who in the theatre is a not very successful actress, triumphs in the role written and directed for her by her spymaster in the real world. Le Carré explores motives, reveals ambiguities, and at the same time spins an exciting yarn.

\section{Commitment and concentration}

Another volume equally appreciated although in complete contrast was Jonathan Miller's States of Mind, sent to me by a colleague with a mildly ironic card wishing me some pleasant light reading. The book comprises some 15 accounts of conversations with experts in psychology, philosophy, sociology, neurophysiology, psychiatry, and related aspects of knowledge, demanding commitment and concentration, especially in unfamiliar disciplines. Contributions to the understanding of mental life are made by engineers and ethologists, logicians and educationalists, neurologists and psychoanalysts and my own training and prejudices made it more or less easy to assess and appreciate the value of individual theories and explanations of human behaviour. The only certainty seems to be that whatever it is that makes us tick, or indeed run down, may be described and partly explained by using different concepts and languages, which have been developed in the course of investigating behaviour with different techniques. The novelist or poet unconstrained by theory may well contribute more to understanding man than the scientist who is shackled by a specific theory.

Perhaps somewhere between the scientist and the creative writer is the biographer, who researches in depth the personal history of his subject, elucidates facts, describes events, and attempts to explain how and why the subject achieved or failed to achieve greatness. Two biographies by Ronald W Clark, the first of Freud (Freud: The Man and the Cause) and the second of Einstein (Einstein: The Life and Times), make fascinating reading. Freud emerges from the pages as ambitious and imaginative and determined to achieve greatness, and, although the origin and development of psychoanalysis are clearly and uncritically described, the man Freud seems to me more substantial than his work. On the other hand, Einstein's theories have been an integral part of the modern revolution in physics, yet his personality remains shadowy, mysterious, and hidden in the pages of his biography.

Reading has indeed been more than usually pleasurable to me recently, contributing not a little to convalescence. My current resolution is to spend less time perusing scientific journals and much more in exploring the infinite world of books.

\title{
Clinical curio: allergy to Brazil nut
}

Although immediate hypersensitive reactions to nuts are known to occur, they are not common. Only two instances of intolerance to nuts were identified in a review of 68 cases of food intolerance and food allergy in children reported recently. ${ }^{1}$ The peanut, which is a legume and not a true nut, has been regarded as a common food allergen." Other nuts have been incriminated less frequently.

I report four cases of children with acute reactions to the Brazil nut (seed of Bertholletia excelsa). The table gives the case histories and management of the four children. IgE concentrations and results of radioallergosorbent test are recorded for three of the children.

Although children allergic to the well recognised food allergenseggs, cows' milk, wheat, meat, fish, and fruit-have been identified, few have required emergency treatment. Brazil nut appears to be a potent allergen, and the association with other atopic symptoms in cases 1-3 and almost certain atopic state of case 4 (IgE above reference range for age and positive result of the radioallergosorbent test) suggests that young atopic children should not be offered this food.

I am grateful to Dr R Fifield of the Supraregional Protein Reference Unit, Cardiff Royal Infirmary, for measuring the total IgE and radioallergosorbent test levels.-DAvID W HIDE, consultant paediatrician, Newport.

Minford AMB, Macdonald A, Littlewood JM. Food intolerance and food allergy in children: a review of 68 cases. Arch Dis Child 1982;57:742-7.

Galant SP. Common food allergens. In: Bierman CW, Pearlman DS, eds. Allergic diseases of infancy, childhood and adolescence. Philadelphia: W B Saunders, 1980:213.

Case histories, management, and clinical findings in four children with acute reactions to Brazil nut

\begin{tabular}{|c|c|c|c|c|c|}
\hline Case No & Sex & $\begin{array}{c}\text { Age } \\
\text { (months) }\end{array}$ & History and management & $\underset{(\mathrm{U} / \mathrm{ml})}{\mathrm{IgE}}$ & $\begin{array}{l}\text { Radioallergosorbent } \\
\text { test results }\end{array}$ \\
\hline 1 & $F$ & 37 & $\begin{array}{l}\text { Cows' milk from birth. Eczema at } 5 \text { months. Ate Brazil nut. Immediate swelling of tongue and respiratory } \\
\text { difficulty. Urticaria on face, chest, arms, and abdomen. Responded to oral promethazine } 10 \mathrm{mg} \text {. }\end{array}$ & & \\
\hline \multirow[t]{2}{*}{2} & $\mathrm{~F}$ & 14 & $\begin{array}{l}\text { Breast fed } 3 \text { months. Eczema/asthma in first year. Handled (did not eat) Brazil nut. Immediate swelling of } \\
\text { lips and eyelids. Bronchospasm and general urticaria. Responded to chlorpheniramine maleate } \\
1 \mathrm{mg} \text { intramuscularly. }\end{array}$ & 285 & $\begin{array}{l}\text { Brazil nut (3) } \\
\text { Egg white (3) }\end{array}$ \\
\hline & & 38 & $\begin{array}{l}\text { Second episode after touching Brazil nut dog had chewed. Generalised urticaria. Swelling of lips and } \\
\text { eyelids. Responded to oral chlorpheniramine and not admitted. Also very allergic to egg. }\end{array}$ & & \\
\hline 3 & $M$ & 27 & $\begin{array}{l}\text { Exclusive breast feeding to } 7 \text { months. Eczema from } 6 \text { months. Asthma from } 13 \text { months. Chewed Brazil nut. } \\
\text { Immediate swelling of lips and tongue. Stridor and severe bronchospasm. Cyanosed and unconscious. } \\
\text { Required active resuscitation. Adrenaline } 1 \text { in } 1000,0.5 \mathrm{ml} \text { subcutaneously; hydrocortisone hydrogen } \\
\text { succinate } 200 \mathrm{mg} \text { intravenously; chlorpheniramine maleate } 10 \mathrm{mg} \text { intramuscularly. }\end{array}$ & 500 & $\begin{array}{l}\text { Brazil nut (3) } \\
\text { House dust mite (3) } \\
\text { Egg white (4) }\end{array}$ \\
\hline 4 & $\mathrm{~F}$ & 34 & $\begin{array}{l}\text { Breast fed. No atopic features. Ate nut toffee. Immediately developed cough, stridor, facial oedema. } \\
\text { Responded to oral chlorpheniramine maleate } 2 \mathrm{mg} \text {. }\end{array}$ & 28 & Brazil nut (2) \\
\hline
\end{tabular}

